\title{
sciforum
}

Conference Proceedings Paper

\section{Sponges (Porifera: Demospongiae) recorded at the South Shetland Islands and near the Antarctic Peninsula during the Argentinian Summer Antarctic Expedition in 2012}

\author{
Alejandro Ariel Fernández $\#^{1}$, Nicolás Agustín Lemiña $\#^{1}$ and Laura Schejter ${ }^{2, *}$ \\ Published: date \\ Academic Editor: name \\ 1 Facultad de Ciencias Exactas y Naturales, Universidad de Buenos Aires, Intendente Güiraldes 2160 - \\ Ciudad Universitaria, Buenos Aires, Argentina. \\ 2 Consejo Nacional de Investigaciones Científicas y Técnicas (CONICET) \& Instituto Nacional de \\ Investigación y Desarrollo Pesquero (INIDEP-ARGENTINA). Paseo Victoria Ocampo №1, 7600, Mar del \\ Plata, Argentina. \\ * Correspondence: schejter@inidep.edu.ar \\ \# Both authors had contributed equally to this study
}

\begin{abstract}
The Argentinian 2012 Summer Antarctic Expedition took place in the Austral summer of 2012. One of its main goals was the study of the benthic communities, considering the biodiversity and the distribution of the species around the Antarctic Peninsula and neighbouring islands. Samples were mainly collected by bottom trawling at eight locations. Sponges were sorted from total catch, photographed, labeled and frozen onboard, while identification was carried out using the classical methodology at the Instituto Nacional de Investigación y Desarrollo Pesquero (INIDEP, Argentina). In this preliminary study we provide data on sponges belonging to the Demospongiae Class. A total of 34 samples were collected and at least 24 species were identified. The most represented Order was Poecilosclerida with 18 species (Isodictya erinacea, I. lankesteri, I. cf. verrucosa, Mycale (Oxymycale) acerata, M. (M.) cf. tridens, Phorbas glaberrimus, P. acantochela, Lissodendoryx (Ectyodoryx) anacantha, L. (E.) ramilobosa, L. (L.) flabellata, Artemisina apollinis, Myxodoryx hanitschi, Clathria (Axosuberites) nidificata, Tedania charcoti, Iophon unicorne, I. cf. aceratum, Myxilla (M.) mollis, Kirkpatrickia aff. coulmani), followed by Haplosclerida with 5 species (Haliclonissa verrucosa, Haliclona sp., Calyx cf. arcuarius, Microxina charcoti, Hemigellius cf. pilosus). The most frequently recorded species was Mycale (O.) acerata followed by species of the genus Isodictya and Lissodendoryx. Some of the recorded species such as Phorbas glaberrimus, Myxodoryx hanitschi, Phorbas cf. acanthochela and Raspailia (Hymeraphiopsis) hentscheli have only scarce records in this region. The results of this study greatly contribute to the knowledge on the distribution and biodiversity of Antarctic sponges, a very important component of the benthic communities.
\end{abstract}

Keywords: Sponges; Demospongiae; Biodiversity; Species distribution; Benthic communities; Antarctica; South Shetland Islands. 


\section{Introduction}

The marine benthic Antarctic communities are often dominated by sessile suspension-feeders such as sponges, cnidarians, bryozoans, ascidians and some bivalves as well [1]. Particularly, sponges are one of the most important components, especially in some regions [2]. In addition, they offer shelter and protection to a great variety of small organisms, from prokaryotic and eukaryotic unicellular organisms to small fish, polychaetes, mollusks, and crustaceans [3].

Comprising more than 8553 species, the Class Demospongiae is by far the largest within the phylum Porifera. From Antarctica and adjacent areas, currently, more than 352 species were reported and this number is expected to be even larger due to other recent discoveries [4].

Since the 19th century, several scientific expeditions have been developed in different regions of Antarctica, nevertheless there are still some areas unsatisfactory sampled that will probably add further data in regards to biodiversity, abundance and distribution of Antarctic sponges [5, 4].

For the mentioned reasons, the aim of this work is to contribute to the knowledge on the distribution and biodiversity of sponge species in areas of the Antarctic Peninsula and neighbouring islands.

\section{Material and Methodology}

Samples were collected at 8 sites during the Argentinean Antarctic Expedition onboard RV "Puerto Deseado" (Figure 1, Table 1), performed between February 13rd and March 24th in 2012 (CAV 2012). All necessary permits for sampling and observational field studies in Antarctica have been obtained by the authors from the competent authorities before the cruises (Dirección Nacional del Antártico, Argentina).

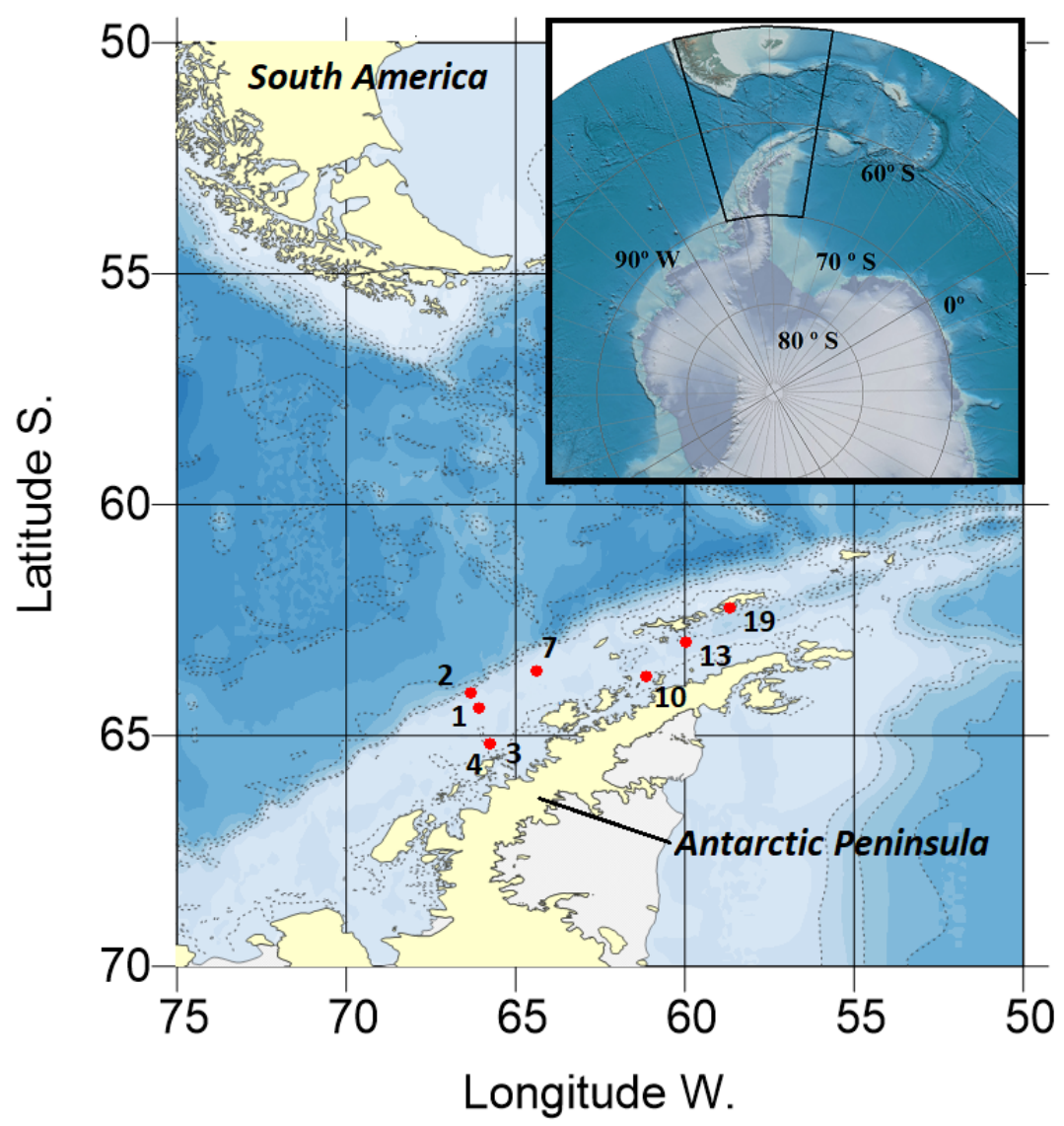

Figure 1. Study area and location of the stations sampled during the 2012 Argentinian Summer Antarctic Expedition. Antarctica map modified from NOAA (see https://www.arcgis.com/home/item.html?id=d13b9d10219e4429974e48368b64e41f) 
Sampling was mainly performed using a bottom trawl net $(6 \mathrm{~m}$ total length, with a $25 \mathrm{~mm}$ mesh on the wings and $10 \mathrm{~mm}$ in the cod end). Samples from station 19 were obtained as bycatch using a home-made longline, in coastal waters in front of "Carlini" Station (Argentina). General characterization of the catches of CAV 2012 was provided by Schejter [6]. Sponge specimens were separated from total catches, photographed and frozen on board. Live colour and complementary data were also acquired during the cruise. Later, in the laboratory (Benthos Laboratory, INIDEP, Argentina), the samples were preserved in a formaldehyde solution or dried for spicule and skeleton preparations.

Identification of the species was performed using the classical taxonomical methodology. In order to study the spicules, the organic matter was digested with a sodium hypochlorite solution, and consecutively washed with water and ethanol according to the known standard procedures before mounting on microscope slides [7]. Spicules were measured and examined with a Leica DM 1000 stereomicroscope. The data for spicule sizes are based on about 25-30 measurements for each spicule category. The skeletal architecture was also studied by light microscopy using a Leica MZ 8 stereomicroscope.

General classification system adopted in this work is the one proposed by Morrow and Cárdenas [8] as followed by the World Porifera Database (http://www.marinespecies.org/porifera/).

\section{Results and Discussion}

For the present study, we considered 34 sponge samples belonging to Class Demospongiae. Samples corresponded to 3 orders, 12 families, 16 genus and at least 24 species (Table 1, Figure 2).

Table 1. Location of the sampling sites and sponge species recorded during the present study.

\begin{tabular}{|c|c|c|c|c|}
\hline Station & LAT (S) & LONG (W) & Depth (m) & Recorded Taxa \\
\hline 1 & $64^{\circ} 24.740^{\prime}$ & $66^{\mathrm{o}} 05.420^{\prime}$ & 327 & Calyx cf. arcuarius \\
\hline 2 & $64^{\circ} 53.639^{\prime}$ & $66^{\mathrm{o}} 20.000^{\prime}$ & 404 & Raspailia (Hymeraphiopsis) hentscheli, Haliclona sp. \\
\hline 3 & $65^{\mathrm{o}} 10.297^{\prime}$ & $65^{\mathrm{o}} 44.207^{\prime}$ & 187 & Mycale (Oxymycale) acerata, Haliclonissa verrucosa \\
\hline 4 & $65^{\circ} 11.134^{\prime}$ & $65^{\circ} 45.827^{\prime}$ & 196 & $\begin{array}{l}\text { Hemigellius cf. pilosus, Lissodendoryx (Ectyodoryx) } \\
\text { anacantha, Microxina charcoti, Clathria (Axosuberites) } \\
\text { nidificata, Isodictya cf. setifera, Haliclona sp., Mycale } \\
\text { (Oxymycale) acerata, Lissodendoryx (Ectyodoryx) ramilobosa }\end{array}$ \\
\hline 7 & $63^{\circ} 36.182^{\prime}$ & $64^{\circ} 21.809^{\prime}$ & 355 & $\begin{array}{l}\text { Isodictya cf. verrucosa, Lissodendoryx (Ectyodoryx) } \\
\text { anacantha, Haliclona sp. }\end{array}$ \\
\hline 10 & $63^{\circ} 43.092^{\prime}$ & $61^{\circ} 07.402^{\prime}$ & 142 & $\begin{array}{l}\text { Kirkpatrickia aff. coulmani, Mycale (Oxymycale) acerata, } \\
\text { Isodictya lankesteri, Tedania (Tedaniopsis) charcoti, } \\
\text { Myxodoryx hanitschi, Phorbas acantochela, Lissodendoryx } \\
\text { (Lissodendoryx) flabellata, Artemisina apollinis, Phorbas } \\
\text { glaberrimus, Myxilla (Myxilla) mollis, Iophon unicorne }\end{array}$ \\
\hline 13 & $62^{\circ} 59.310^{\prime}$ & $59^{\circ} 57.246^{\prime}$ & 989 & $\begin{array}{l}\text { Mycale (Mycale) cf. tridens, Iophon cf. aceratum, Iophon } \\
\text { unicorne }\end{array}$ \\
\hline 19 & $62^{\circ} 13.873^{\prime}$ & $58^{\circ} 39.919^{\prime}$ & 43 & Isodictya erinacea, Mycale (Oxymycale) acerata \\
\hline
\end{tabular}


The 1st International Electronic Conference on Biological Diversity, Ecology, and Evolution, 15-31 March 2021

The most represented Order was Poecilosclerida with 18 species (Isodictya erinacea, I. lankesteri, I. cf. verrucosa, Mycale (Oxymycale) acerata, M. (M.) cf. tridens, Phorbas glaberrimus, P. acantochela, Lissodendoryx (Ectyodoryx) anacantha, L. (L.) flabellata, L. (E.) ramilobosa, Artemisina apollinis, Myxodoryx hanitschi, Clathria (Axosuberites) nidificata, Tedania (Tedaniopsis) charcoti, Iophon unicorne, I. cf. aceratum, Myxilla (Myxilla) mollis, Kirkpatrickia aff. coulmani), followed by Haplosclerida with 5 species (Haliclonissa verrucosa, Haliclona sp., Calyx cf. arcuarius, Microxina charcoti, Hemigellius cf. pilosus).
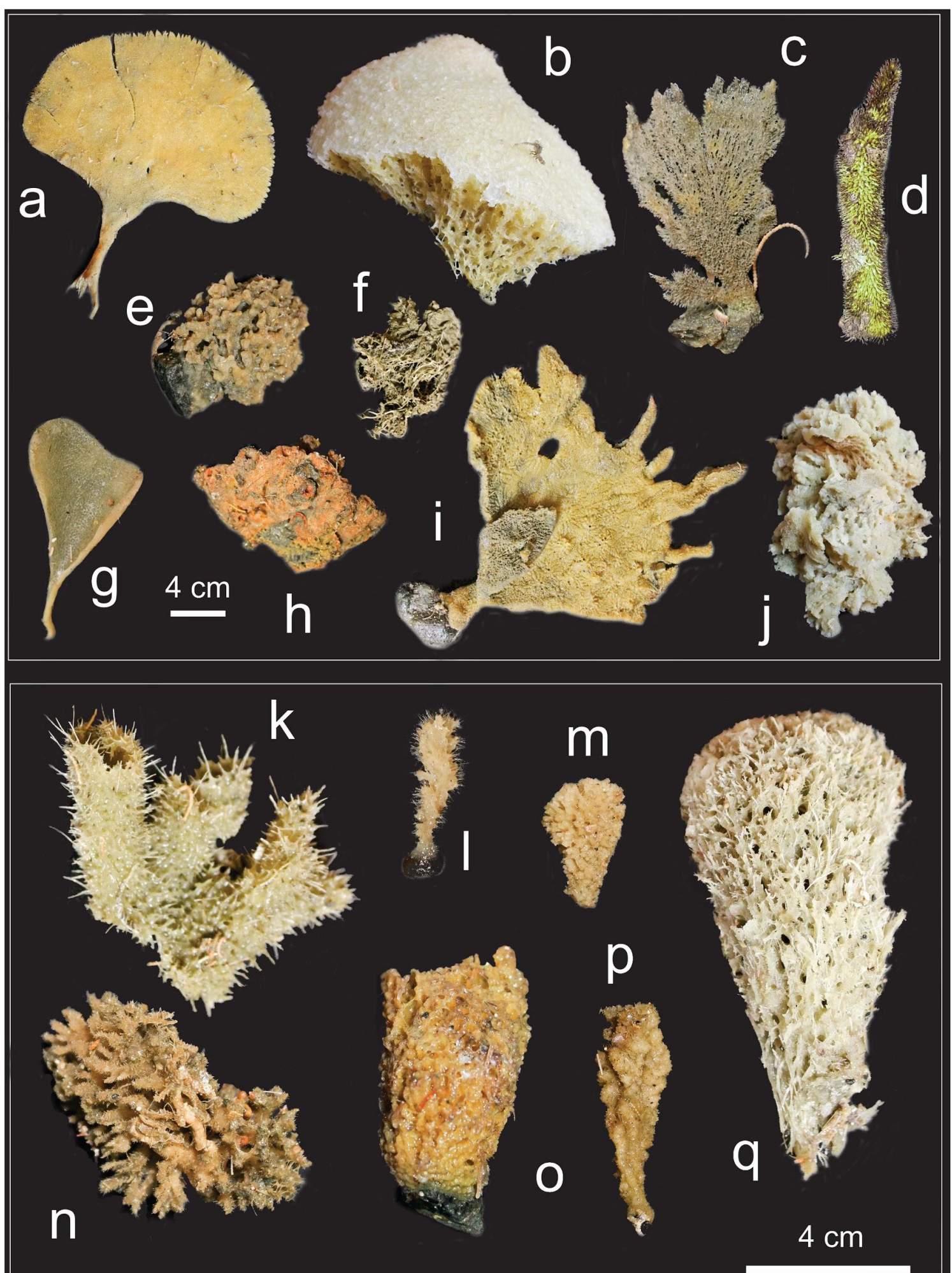
Figure 2. Photographs of several sampled species. a) Isodictya lankesteri; b) Mycale (O.) acerata; c) Kirkpatrickia aff. coulmani; d) Isodictya erinacea; e) Tedania (T.) charcoti; f) Mycale (M.) cf. tridens; g) Calyx cf. arcuarius; h) Artemisina apollinis; i) Lissodendoryx (L.) flabellata; j) Haliclonissa verrucosa; k) Microxina charcoti; l) Raspailia (H.) hentscheli; m) Lissodendoryx (E.) anacantha; n) Clathria (A.) nidificata; o) Myxodoryx hanitschi; p) Lissodendoryx (E.) ramilobosa; q) Hemigellius cf. pilosus.

The most frequently recorded species was Mycale (Oxymycale) acerata (Kirkpatrick 1907) (Figure 2b), reported in $50 \%$ of the sampled sites (stations $3,4,10,19$ ). This is a very common and conspicuous species in Antarctica and our specimens perfectly fit the descriptions previously provided by Ríos and Göcke \& Janussen [5, 4].

Lissodendoryx (Ectyodoryx) anacantha (Hentschel, 1914) (Figure 2m) was recorded twice, in stations 4 and 7, in the distributional range previously reported by Hentschel [9], Koltun [10] and Burton [11]. Our specimens perfectly fit the description and spicule dimensions provided in the mentioned literature.

The sponge Iophon unicorne (Topsent, 1907) was also recorded twice, at stations 10 and 13 . This is a very frequently reported species in Antarctic and subantarctic waters, having a high morphological variability $[5,10,4]$.

Some of the recorded species (Microxina charcoti (Topsent 1916), Isodictya erinacea (Topsent, 1916), I. cf. setifera, I. cf. verrucosa, Tedania (Tedaniopsis) charcoti (Topsent 1907), Clathria (Axosuberites) nidificata (Kirkpatrick, 1907), Artemisina apollinis (Ridley \& Dendy, 1886), Myxilla (Myxilla) mollis (Ridley \& Dendy, 1886), Calyx cf. arcuarius, Haliclonissa verrucosa (Burton, 1932), Lissodendoryx (Ectyodoryx) ramilobosa (Topsent, 1916); Figure 2) were commonly reported in Antarctica or have their records mainly in our study area $[12,10,5,4]$. In these cases, our specimens fit very well with the descriptions provided in the mentioned references.

On the other hand, we also recorded some species that were only scarcely reported or were reported for other regions in Antarctic waters, as follows:

- Lissodendoryx (Lissodendoryx) flabellata (Burton, 1929) (Figure 2i). Reported by Koltun [10] and Vacelet \& Arnaud [13]. It was recorded at station 10 in the present study. Our specimen is erect and flabellate, beige in color, with a conulose surface. It was settled on a rock. The skeleton is reticulate, with a dermal skeleton conformed by tornota. Spicules are styles of 460-510 by 20-30 $\mu$ m; tornota with spiny ends of 290-340 by 7.5-10 $\mu \mathrm{m}$; arcuate isochelae 20-22.5 $\mu \mathrm{m}$. This is the first report of this species in this Antarctic sector.

- Raspailia (Hymeraphiopsis) hentscheli (Van Soest \& Hooper, 2020) (Figure 21). Reported previously by Hentschel [9], Ríos [5] and Göcke \& Janussen [4] in Antarctic areas. Our specimens, collected at station 2, are small, were settled on pebbles, and presented an erect morphology of about 2-3 cm height, having a hispid surface. They perfectly fit the description provided by Ríos [5], and have long styles of about $2250 \mu \mathrm{m}$, a second category of styles of 490 by $15 \mu \mathrm{m}$, and the characteristic acanthostyles of the genus, of $175-350$ by $12-20 \mu \mathrm{m}$.

-Kirkpatrickia aff. coulmani (Figure 2c). Reported in the literature after its description by Koltun [10]; Burton [11]; Vacelet \& Arnaud [13]; Ríos [5], but not reported in our study area. Our specimen, collected at station 10, has an erect, flabellate, fan morphology, very soft, beige in color, and it was settled on a pebble, sharing the substrate with a primnoid octocoral. Its surface is conulose, and presents a plumoreticulate skeleton. Spicules are smooth styles of $510-590$ by $20 \mu \mathrm{m}$ and tornota with mucronate ends of 310-370 by $7.5 \mu \mathrm{m}$. Our specimen is in accordance with the description provided by Burton [11] and Koltum [10], having smooth styles instead of the microspinulated acanthostyles described by Kirkpatrick [14]. However, the original description shows micro spines, also mentioned by Ríos [5]. Hence, this identification should be taken with caution.

-Phorbas glaberrimus (Topsent, 1916). Previously reported in Antarctic and subantarctic waters by Goodwin et al. [15, 16], Koltun [10] and Ríos [5]. It was collected in station 10. It is a massive sponge, beige to peach in color, with a surface covered with papillae. Spicules are acanthostyles from $180-340$ by $10 \mu \mathrm{m}$, straight fusiform oxea/tornota of $430-520$ by $10 \mu \mathrm{m}$ and isochelae $20-28 \mu \mathrm{m}$. Our specimens are in accordance with the descriptions provided in the references. 
-Myxodoryx hanitschi (Kirkpatrick, 1907) (Figure 2o). Reported by Hentschel [9], Topsent [17], Koltun [10] and Göcke \& Janussen [4]. Our specimens were collected at station 10, are massive, beige in color and were settled on pebbles. They fit very well with the extended description provided by Göcke \& Janussen [4], and have smooth styles of $360-520$ by $12.5-15 \mu \mathrm{m}$, acanthostyles of $200-275$ by 7.5-10 $\mu \mathrm{m}$ and tornota of $215-345$ by 7.5-10 $\mu \mathrm{m}$.

-Phorbas cf. acanthochela. This species is only known from its original description, made by Koltun [10]. This massive, beige specimen with a verrucose surface was collected at station 10 . It has styles ranging from $412-590$ by $15-20 \mu \mathrm{m}$, acanthostyles (some with an enlarged base) of 155-207 by 7.5-10 $\mu \mathrm{m}$ and robust chelae 25-43 $\mu \mathrm{m}$. Although our specimen is in accordance with Koltun's description and figures, we prefer to keep the identification with caution, due to the rarity of the species, until more measurements could be done.

- Haliclona sp. At least 3 specimens from stations 2, 4 and 7 presented the characteristic skeleton and oxea of the genus, with no microscleres. More measurements and comparisons should be done before the specific identification could be provided.

-Hemigellius cf. pilosus (Figure 2q). This rare species was previously reported by Kirckpatrick [14], and Goodwin et al. [16] and some Antarctic local field guides. Our specimen is a fragment, beige in color, erect, with a hispid or pilose surface, that was collected at station 4. Spicules are oxeas 490-600 by $15-20 \mu \mathrm{m}$ and $C$ sigmae of $20-45 \mu \mathrm{m}$. If we finally confirm the identification, the bathymetric range should be updated from shallow waters up to $196 \mathrm{~m}$.

- Mycale (Mycale) cf. tridens. Our specimen was collected at station 13, and it is a fragmented and bad preserved specimen (Figure 2f). The morphology and skeleton are typical of the genus Mycale (see Ríos [5]), and have mycalostyles of $640-750$ by x $15 \mu \mathrm{m}$, anisochelae of $100 \mu \mathrm{m}$ and sigmae of 80 $\mu \mathrm{m}$. We need to take more measurements of the specimen, to look for the anisochelae II and sigmae II to confirm the identification.

-Iophon cf. aceratum. This species was reported by Hentschel [9], Burton [18] and Koltun [10], and it was not previously reported in our study area. Our specimen was collected at station 13 , and it is a massive fragment, dark brown in color and with a pilosus surface. The sizes of the spicules are in accordance with the original description made by Henstchel [9], with mucronate styles 530-640 by 20-25 $\mu \mathrm{m}$, acanthotylotes of 370-405 by $10 \mu \mathrm{m}$ and anisochelae of $25-30 \mu \mathrm{m}$. However, we couldn't find bipocilli, perhaps due to the small size described (12-13 $\mu \mathrm{m}$ in the original description). We should confirm the presence of these microscleres before confirming the specific identification and updating the distributional range in Antarctica.

\section{Conclusions}

The results of this study greatly contribute to the knowledge on the distribution and biodiversity of Antarctic sponges, a very important component of the benthic communities. Sectors near the stations 4 and 10 should probably require more studies regarding sponge fauna, as it was demonstrated that the highest richness of this study was reported in both areas.

Acknowledgments: This study was partially supported by Dirección Nacional del Antártico (Argentina), INIDEP and PICT 2019-4233.

Author Contributions: This study was the final project of the "Biological Oceanography" Course (Universidad de Buenos Aires, Argentina) developed by AF and NL, directed by LS. All authors contributed to the writing and revising of the paper.

Conflicts of Interest: No competing interests declared 
The 1st International Electronic Conference on Biological Diversity, Ecology, and Evolution, 15-31 March 2021

\section{References}

[1] Orejas, C.; Gili, J.M.; Arntz, W.E.; Ros, J.D; López, P.J.; Teixidó, N.; Filipe, P. Benthic suspension feeders, key players in Antarctic marine ecosystems? Contrib Sci 2000, 1, 299-311.

[2] Downey, R.; Griffiths, H.; Linse, K.; Janussen, D. Diversity and Distribution Patterns in High Southern Latitude Sponges. PloS one 2012, 7. e41672.

[3] Schejter, L. Phylum Porifera: Las esponjas. In Los invertebrados marinos; Calcagno, J. Ed.; Fundación de Historia Natural Félix de Azara: Ciudad Autónoma de Buenos Aires, Argentina, 2014; pp. 49-65.

[4] Göcke, C.; Janussen, D. Demospongiae of ANT XXIV/2 (SYSTCO I) Expedition-Antarctic Eastern Weddell Sea. Zootaxa. 2013, 3692, 28, 10.11646/zootaxa.3692.1.5.

[5] Ríos López, P. Esponjas del Orden Poecilosclerida de las campañas españolas de Bentos Antártico. PhD Thesis, Universidad de Santiago de Compostela, Santiago de Compostela, Spain, April 2006.

[6] Schejter, L. Informe de Campaña Antártica de Verano 2011/2012. Buque Oceanográfico ARA "Puerto Deseado". INIDEP Technical Cruise Report №5/2012, 2012. Mar del Plata, Argentina, 22pp.

[7] Hajdu, E.; Peixinho, S.; Fernandez, J.C.C. Esponjas marinhas da Bahia: guia de campo e laboratório; Museu Nacional, Rio de Janeiro, 2011; 276 p.

[8] Morrow, C.; Cárdenas, P. Proposal for a revised classification of the Demospongiae (Porifera). Front Zool 2015, 12, 7. 10.1186/s12983-015-0099-8.

[9] Hentschel, E. Monaxone Kieselschwämme und Hornschwämme der Deutschen Südpolar-Expedition 1901-1903. Deutsche Südpolar-Expedition 1914, 15 (1), 35-14.

[10] Koltun, V.M. Sponges of the Antarctic. 1 Tetraxonida and Cornacuspongida. In Biological Reports of the Soviet Antarctic Expedition (1955-1958); Pavlovskii, E.P., Andriyashev, A.P., Ushakov, P.V., Eds.; Akademiya Nauk SSSR: Moscow-Leningrad, USSR, 1964; pp. 6-133, 443-448. [Israel Program for Scientific Translation, Jerusalem, Israel, 1996.]

[11] Burton, M. Sponges. In Discovery Reports.; Cambridge University Press: London, UK, 1932; Volume 6, pp. 237-392.

[12] Burton, M. Porifera: Part II: Antarctic Sponges. In British Antarctic ("Terra Nova") Expedition, 1910. Natural History Reports. Zoology. Vol. VI; British Museum (Natural History): London, UK, 1929, 6, pp. 393-458.

[13] Vacelet, J.; Arnaud, F. Invertébrés marins des XIIème et XVème Expéditions Antarctiques françaises en Terre Adélie. 2. Démosponges. Téthys 1972, S4, 9-24.

[14] Kirkpatrick, R. Preliminary report on the Monaxonellida of the National Antarctic expedition. Ann.Mag. nat. Hist. 1907, 7(20), 271-291.

[15] Goodwin, C.; Brewin, P.E.; Brickle, P. Sponge biodiversity of South Georgia island with descriptions of fifteen new species. Zootaxa 2012, 3542, 1-48.

[16] Goodwin, C.E.; Berman, J.; Hendry, K.R. Demosponges from the sublittoral and shallow-circalittoral $(<24 \mathrm{~m}$ depth) Antarctic Peninsula with a description of four new species and notes on in situ identification characteristics. Zootaxa 2019, 4658 (3), 461-508. 
The 1st International Electronic Conference on Biological Diversity, Ecology, and Evolution, 15-31 March 2021

[17] Topsent, E. Spongiaires. In Deuxième Expédition Antarctique Française (1908-1910) Commandée par le Dr. Jean Charcot. Sciences Physiques: Documents Scientifiques (Paris).; Joubin, L., Ed.; Masson \& Cie: Paris, France, 1917; S4, pp. 1-88.

[18] Burton, M. Sponges. In Further Zoological Results of the Swedish Antarctic Expedition 1901-03 under the Direction of Dr. Otto Nordenskjöld.; Sixten Bock. Norstedt \& Söner: Stockholm, Sweden, 1934, Volume 3 (2), pp. 1-58.

(C) 2020 by the authors; licensee MDPI, Basel, Switzerland. This article is an open access article distributed under the terms and conditions of the Creative Commons by Attribution (CC-BY) license (http://creativecommons.org/licenses/by/4.0/). 